\title{
HYPE or HOPE: the prognostic value of infiltrating immune cells in cancer
}

\author{
Tristan A Barnes ${ }^{1}$ and Eitan Amir ${ }^{*}, 1$ \\ ${ }^{1}$ Department of Medical Oncology and Hematology, Princess Margaret Cancer, Toronto, ON M5G 2M9, Canada
}

\begin{abstract}
Interactions between immune and malignant cells have been known to have clinical relevance for decades. The potential for immune control is now being therapeutically enhanced with checkpoint inhibitors and other novel agents to improve outcomes in cancer. The importance of the immune infiltrate as a prognostic marker is increasingly relevant. In this minireview, we present an overview of the immune infiltrate and its spatial organisation, and summarise the prognostic value of immune cells in different cancer types. International collaborative efforts are standardising histopathologic reporting of the immune infiltrate, to allow application of these parameters in the clinical and research settings. In general terms, a 'pro-inflammatory' tumour microenvironment and infiltrating CD8-expressing $T$ lymphocytes are associated with improved clinical outcomes in a broad range of tumour types. The inhibitory function of other immune cells, for example, myeloid-derived suppressor cells and regulatory T cells, appear to have a major role in disrupting the capacity for the immune control of cancers.
\end{abstract}

The immune system and malignant cells interact via a complex network. The importance of immune function in tumour development and control has been acknowledged for decades. As immunotherapy enters clinical practice, these underpinnings have more relevance as we try to identify predictive biomarkers for benefit from new therapies. The seminal papers describing the 'hallmarks of cancer' pronounced the capacity to avoid immune destruction as one of the requirements for malignancy (Hanahan and Weinberg, 2011). There is now a vast literature supporting immunosurveillance as a significant contributor to the natural history of malignancy. The interaction between tumours and the immune system has been described in three scenarios of 'immunoediting' (Schreiber et al, 2011); specifically: elimination (where immune surveillance successfully eradicates malignant cells); equilibrium (where the immune system exerts control over abnormal cells) and escape (where tumour cells evade immune mechanisms allowing growth and metastasis) (Mittal et al, 2014). In this mini-review, we aim to define the immune infiltrate and its spatial organisation as well as summarising the prognostic value of immune cells in different solid cancers.

\section{SUBTYPES OF IMMUNE CELL INFILTRATE}

Historically, studies have focused on the interaction between cytotoxic $\mathrm{T}$ lymphocytes and cancer cells. The role of other immune cells is also now recognised as contributing to the complex immune response in cancer, some of which promote tumour control and others facilitate cancer progression (Table 1; Figure 1).

\section{LOCATION AND SPATIAL ORGANISATION OF THE} IMMUNE CELL INFILTRATE

Although the distinction between peritumoural, stromal and intratumoural lymphocytes is made histopathologically (Table 2), this is likely an artificial segregation as this is a dynamic network that allows chemokine-generated cell movement between these areas.

A qualitative description of the interplay between tumour and immune cell infiltrate has been termed the 'immune contexture', and includes the location of specific immune cells, tertiary lymphoid structures (ectopic lymphoid aggregates that are generated during immune stimulation and exhibit structural characteristics of lymphoid organs), and the chemokines and cytokines involved in this microenvironmental organisation (Fridman et al, 2011). Methods for describing the immune infiltrate are a limitation of current pathological reporting. There remains a lack of consensus regarding reporting of tumourinfiltrating lymphocytes (TILs), including methods to subtype the infiltrating cells and their spatial organisation. International working groups are trying to create and validate reporting guidelines (Salgado et al, 2015). Immunophenotyping of the

*Correspondence: Dr E Amir; E-mail: eitan.amir@uhn.ca 
Table 1. Cell types in the tumour immune infiltrate

\begin{tabular}{|c|c|c|}
\hline & Expression & Function \\
\hline \multicolumn{3}{|l|}{ Lymphoid } \\
\hline Cytotoxic T lymphocyte & CD3, CD8 & $\begin{array}{l}\text { Recognise and lyse target cells through release of perforin and granzymes. Activated by dendritic cell } \\
\text { antigen presentation via major histocompatibility complex (MHC) Class I antigen to T cell receptor. } \\
\text { Apoptosis is induced in cells expressing specific antigen }\end{array}$ \\
\hline $\begin{array}{l}\text { Regulatory T lymphocyte (also } \\
\text { called suppressor T cells) }\end{array}$ & $\begin{array}{l}\text { CD3, CD4, } \\
\text { CD25, FOXP3 }\end{array}$ & $\begin{array}{l}\text { Serve to maintain tolerant to self antigens; inhibit dendritic cell function of antigen presentation and thus } \\
\text { inhibits both the expansion and the differentiation of T effector cells. Polyclonal Tregs appear to modulate } \\
\text { differentiation and cell trafficking }\end{array}$ \\
\hline T helper lymphocyte (Th cell) & CD4 & $\begin{array}{l}\text { Help to modulate immune responses. Activate and promote growth of cytotoxic T cells; maximise activity } \\
\text { of phagocytes through interaction with } \mathrm{MHC} \text { Class II; role in B cell antibody class switching (e.g., from } \\
\text { immunoglobulin-M to immunoglobulin-G) }\end{array}$ \\
\hline Natural killer cell (NK) & CD16, CD56 & $\begin{array}{l}\text { A subset of cytotoxic lymphocytes that can be activated in the absence of MHC Class I antigen } \\
\text { presentation, thus an important component of the innate immune system }\end{array}$ \\
\hline \multicolumn{3}{|l|}{ Myeloid } \\
\hline Dendritic cells & CD40 & $\begin{array}{l}\text { Act to process and present antigen on MHC Class I, and via co-stimulatory molecules they serve to } \\
\text { activate T lymphocytes }\end{array}$ \\
\hline $\begin{array}{l}\text { Myeloid-derived suppressor cells } \\
\text { (MDSC) }\end{array}$ & CD11b, CD66b & $\begin{array}{l}\text { Pathologically activated immature myeloid cells, with morphological and phenotypical similarity to } \\
\text { mononuclear and polymorphonuclear cells. Prevent activation of } \mathrm{T} \text { cells and have a role in promoting } \\
\text { tumour growth and metastasis }\end{array}$ \\
\hline Macrophages & CD68 & $\begin{array}{l}\text { Part of the innate immune defence with phagocytic capacity, and also have a role in adaptive immunity } \\
\text { through activation of other immune cells via cytokine release. M1 macrophages are pro-inflammatory } \\
\text { (largely driven by interferon (IFN)-gamma); M2 macrophages release anti-inflammatory cytokines such as } \\
\text { IL4, IL10, TGF-beta and nuture tolerance }\end{array}$ \\
\hline
\end{tabular}

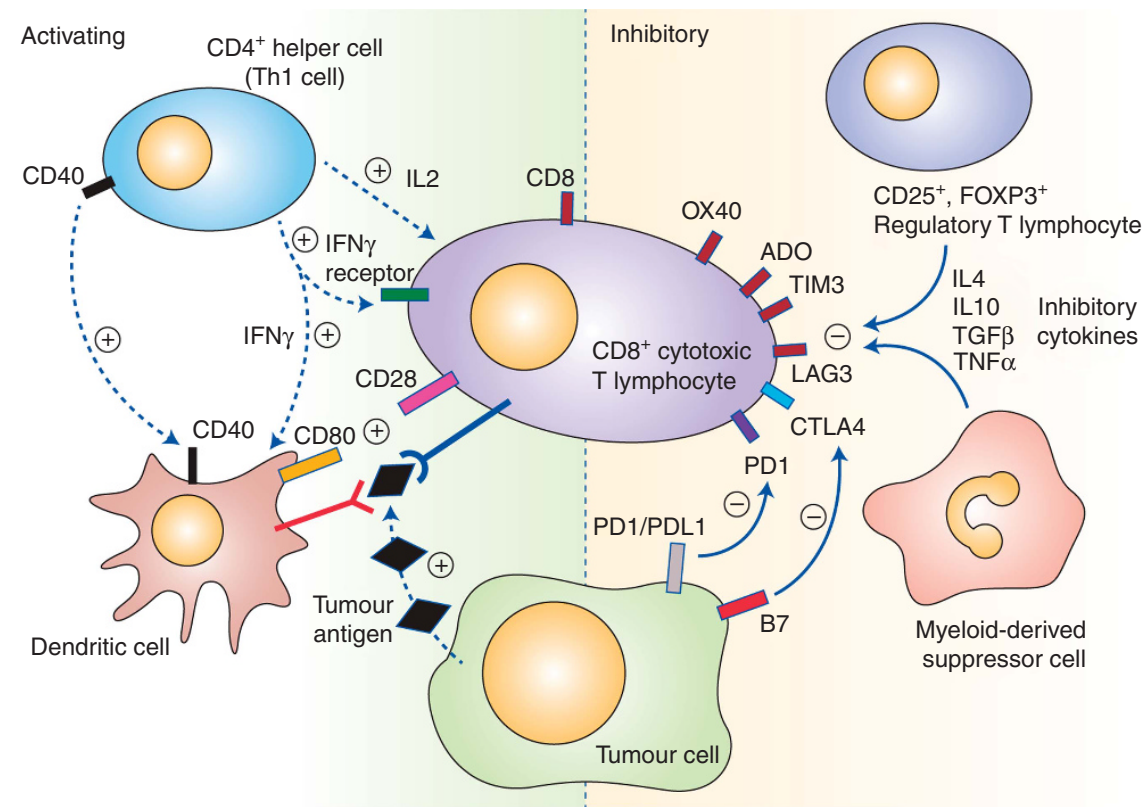

Figure 1. Pathways affecting cytotoxic T lymphocyte activity within the tumour microenvironment.

\section{Table 2. Location of the immune infiltrate}

\begin{tabular}{|l|l|}
\hline Infiltrate & Location \\
\hline Intratumoural & Within the mass (or nest) of malignant cells, with direct proximity between cancer and immune cells \\
\hline Stromal & In the surrounding connective tissues and blood vessels \\
\hline Peritumoural & Around the tumour and can refer to cells at the advancing margin of the tumour, in the stroma or the tissues adjacent to the tumour \\
\hline
\end{tabular}

immune infiltrate by immunohistochemistry or immunofluorescence staining can be performed in tissue samples, or after generation of cell suspensions that are generated by mechanical or enzymatic breakdown of fresh tumour tissue (Stoll et al, 2015). The use of sectioned tissue specimens allows spatial understanding of cell position relative to tumour cells, however, similar to the use of cell suspension, is limited by challenges in antigen retrieval (capacity to bind identifying/specific proteins of interest) and poor standardisation. Novel approaches such as mRNA characterisation of immune co-regulated genes may help to identify and characterise the immune infiltrate (Stoll et al, 2015). Metaanalytical data suggest that in most cancers, the immune infiltrate is heterogeneous and there is limited reproducibility of leukocyte subtypes (Stoll et al, 2015). Although the presence of T cells is clearly important, the interplay between tumour antigens and major histocompatibility complex (MHC) molecules for antigen presentation is critical for efficient $\mathrm{T}$ cell activation. High affinity of the targeted peptides for MHC is required for strong stimulation of 
$\mathrm{T}$ cells to secrete cytokines and produce tumour eradication or control (Engels et al, 2013). The specific antigenicity of coding exons in mutated cancer genes is an area of research and the capacity to sequence whole genomes with greater speed and reduced cost is enhancing the capacity to identify potentially antigenic mutations.

\section{PROGNOSTIC VALUE OF INFILTRATING IMMUNE CELLS}

The prognostic value of lymphocytes in stromal, peritumoural and intratumoural locations remains unclear, with conflicting data from different tumour sites. Peritumoural lymphocytes at the advancing tumour margin and those in direct contact with tumour cells have been purported to carry the most prognostic weight particularly in some disease sites (see below). In general terms, a 'pro-inflammatory' tumour microenvironment and infiltrating CD8-expressing $\mathrm{T}$ lymphocytes are associated with improved clinical outcomes in a broad range of tumour types. In contrast, the inhibitory function of other immune cells, for example, myeloid-derived suppressor cells and regulatory $\mathrm{T}$ cells (Tregs) appear to have a major role in disrupting the capacity for the immune control of cancers and are therefore associated with worse outcome.

Perhaps counter-intuitively, favourable outcomes have also been observed in tumours infiltrated by inhibitory immune cells, for example, forkhead box P3-positive regulatory T cells (FOXP3) cells in colorectal cancer. This may represent a feedback loop in the context of an existing anti-tumour immune response and thus actually indicate increased tumour immunogenicity (Gajewski et al, 2013). Myeloid-derived suppressor cells (MDSC) and tumour-associated macrophages are both capable of negative regulation of innate and adaptive immune pathways. MDSCs have a role in tumour growth and metastasis via promotion of immune privilege (ability to tolerate the introduction of antigens without eliciting an inflammatory immune response), tumour microenvironment remodelling, establishment of a pre-metastatic niche (a scenario where non-cancer cells promote future metastasis) and interaction with tumour to promote differentiation, invasion and angiogenesis (Marvel and Gabrilovich, 2015). There is evidence that MDSC expansion is associated with more advanced stages of malignancy in multiple cancer types and also correlates with poor prognosis independent of tumour burden (Ugel et al, 2015). Paradoxically, anti-tumour immunity also leads to selective pressure on malignant cells, which ultimately leads to survival of tumour cells with reduced immunogenicity (Shankaran, 2001). There are also data supporting the hypothesis that tumourinfiltrating immune cells can promote invasion and metastases (Man et al, 2013), which may in part explain the heterogeneity of results between studies examining this topic.

\section{TUMOUR-SPECIFIC PROGNOSTIC VALUE}

Breast cancer. In breast cancer, the presence of TILs is associated with improved prognosis in human epidermal growth factor receptor 2 (HER2) positive and triple negative breast cancers (TNBC), but not in luminal subtypes. In addition, the recognition of the prognostic value of the immune infiltrate has been the basis for establishing a breast cancer immunological grade (Salgado et al, 2015).

Independent of other clinicopathological prognostic factors or chemotherapy regimens, multiple studies have confirmed stromal TILs are associated with higher rates of pathological complete response (pCR) to neoadjuvant chemotherapy in all subgroups evaluated (including ER positive, HER2-positive tumours) (Dushyanthen et al, 2015). However, these differences in response only appear to translate into improved longer term outcomes in non-luminal tumours.

A meta-analysis of 25 published studies comprising over 22000 patients, failed to show that immune infiltrates are associated with overall survival (OS) in unselected breast cancer patients, but did find such an association in TNBC (hazard ratio (HR): $0.79 ; 95 \%$ confidence interval (CI): 0.71-0.87). CD8-expressing lymphocytes were associated with improved disease-free survival (DFS; HR: 0.69; 95\% CI: 0.56-0.84) and breast cancer-specific survival (HR: 0.78 ; $95 \%$ CI: $0.71-0.86)$ in the overall population, whereas the FOXP3-expressing lymphocytes were associated with worse DFS (HR: 1.47; 95\% CI: 1.06-2.05) and OS (HR: 1.50; 95\% CI: 1.15-1.97, $P=0.004$ ) (Mao et al, 2016).

Clinical trials have not reported an association between TIL, nuclear grade or histopathological grade in TNBC with most making the assumption that TNBC are high grade (Adams et al, 2014). It remains uncertain whether this association may be explained partly by response to chemotherapy; lower grade luminal tumours have lesser response to cytotoxic therapy and are less frequently associated with infiltrating immune cells.

A Th1 immune phenotype and mRNA profiles consistent with immune activation have also been associated with response to neoadjuvant chemotherapy (Denkert et al, 2015). There is more variability in results seen in trials reporting outcome for CD4expressing $\mathrm{T}$ lymphocytes and FOXP3-expressing Tregs. The presence of Tregs prior to chemotherapy is associated with higher probability of attaining a pathological complete response (pCR), which probably reflects their association with a higher number of CD8-expressing cells. A high ratio of CD8:FOXP3 cells and a lower proportion of FOXP3 at the end of neoadjuvant chemotherapy may have a more meaningful prognostic value (Dushyanthen et al, 2015).

The current working group have recommended semi-quantitative assessment of stromal TILs and at this stage do not advocate for sub-classification of lymphocytes (Salgado et al, 2015). This is due to both the greater reproducibility of stromal TIL measurement compared with intratumoural TILs, which are difficult to distinguish from malignant cells in standard H\&E sections, and the fact that in TNBC and HER2-positive breast cancer, the prognostic power of TILs persists among all subtypes of infiltrating immune cells (Salgado et al, 2015).

Colorectal cancer. Several scoring systems have been proposed for quantifying the inflammatory response in colorectal cancer. These include the Jass score, the Immunoscore and the Klintrup-Mäkinen grade of overall peritumoural inflammation (Park et al, 2014). There is evidence that TILs are associated with greater prognostic value than the American Joint Committee on Cancer TNM stage (Jochems and Schlom, 2011). In a meta-analysis of nine trials examining tumour inflammation in colorectal cancer, the pooled HR confirmed an OS benefit for patients with prominent TILs compared with those without, with a HR of 0.59 (95\% CI: $0.48-0.72, P<0.001)$ and a HR for cancer-specific survival of 0.40 (95\% CI: $0.27-0.61, P<0.001$ ). There were differences between all the studies in the thresholds used to determine TIL positivity of tumours, for example, some used mean or median cut offs, others used high $v$ s low scores of KlintrupMäkinen or Jass scores (Mei et al, 2014). The evaluation of T cell subsets and specific location of lymphocytic infiltrate did not show strong prognostic value, specifically CD3, CD8, FOXP3 and at different sites (tumour centre, peritumoural stroma and invasive tumour margin) were examined. CD3-positive cells at the invasive margin had OR for DFS of 0.4 (95\% CI: 0.35-0.68) and for OS of 0.63 (95\% CI: $0.42-0.93$ ). This analysis was limited by significant inter-study heterogeneity (Mei et al, 2014). This contrasts to earlier individual study data showing statistically significant association between the type of immune cell density at the centre of the tumour or the infiltrating margin and patient outcome (Jochems and Schlom, 2011). 
Ovarian cancer. In a meta-analysis of 10 studies comprising 1815 patients with treated ovarian carcinoma (Hwang et al, 2012), presence of intra-epithelial $\mathrm{T}$ lymphocytes was associated with improved OS (pooled HR for death 0.45 , 95\% CI: $0.34-0.58, P<0.001$ ). CD3- and CD8-expressing lymphocytes were both examined, and both conferred a survival advantage; CD8 was examined more frequently and demonstrated a larger magnitude of effect on OS than CD3 (pooled HR: 0.46 and 0.57, respectively) (Hwang et al, 2012).

This positive association between CD8-expressing lymphocytes and clinical outcome is also observed in the assessment of patients before treatment and following neoadjuvant chemotherapy. Data on CD3-expressing lymphocytes, B cells and NK cells are less clear (Santoiemma and Powell, 2015). There are conflicting data regarding FOXP3-positive Tregs, with a few studies demonstrating superior outcome, but most studies suggesting a negative impact on survival outcomes through inhibition of cytotoxic T cell activity (Santoiemma and Powell, 2015). The measured absolute number of infiltrating cells may not be as important as the proportion of CD8-expressing cells relative to all infiltrating cells. The prognostic value of intratumoural CD8-positive lymphocytes appears superior even to the adequacy of surgical debulking in prognosticating for both progression free survival and OS (Zhang, 2003).

Non-small cell lung cancer. In a meta-analysis of 29 trials with over 86000 patients, high levels of CD8-expressing cells infiltrating the tumour or in the tumour stroma of non-small cell lung cancer (NSCLC) specimens were associated with better OS (HR: 0.76 and 0.80 , respectively) compared with tumours without lymphocytes present. CD3 expression also demonstrated similar findings; pooled HR for OS 0.65 (95\% CI: $0.50-0.84, P=0.001)$ for stromal CD3 cells and 0.66 (95\% CI: $0.45-0.97, P=0.03)$ for intratumoural CD3 cells. Presence of intratumoural CD4-expressing cells between the tumour cells resulted in improved OS (HR: 0.65; 95\% CI: $0.46-$ $0.91, P=0.01)$. Despite a higher effect size, a significant association

Table 3. Studies examining the prognostic impact of infiltrating immune cells in melanoma

\begin{tabular}{|c|c|c|c|c|}
\hline Study & Number & Result & Association & Cell type \\
\hline $\begin{array}{l}\text { (Kakavand } \\
\text { et al, 2015) }\end{array}$ & 60 & $\begin{array}{l}\text { Positive correlation between CD3, CD4 and CD8 cells in sentinel node and DFS/OS; } \\
\text { PD1 + lymphocytes associated with worse outcome }\end{array}$ & $\begin{array}{l}\text { Positive } \\
\text { association }\end{array}$ & $\begin{array}{l}\text { CD3, CD4 and } \\
\text { CD8 }\end{array}$ \\
\hline $\begin{array}{l}\text { (Saldanha et al, } \\
\text { 2017) }\end{array}$ & 655 & $\begin{array}{l}\text { Higher TILs are associated with better prognosis; confirms value of a simplified numerical } \\
\text { TIL scoring system }\end{array}$ & $\begin{array}{l}\text { Positive } \\
\text { association }\end{array}$ & TIL \\
\hline $\begin{array}{l}\text { (Park and Kim, } \\
\text { 2017) }\end{array}$ & 177 & $\begin{array}{l}\text { Density of lymphocytes in the peritumoural and intratumoural regions were both } \\
\text { prognostic }\end{array}$ & $\begin{array}{l}\text { Positive } \\
\text { association }\end{array}$ & TIL \\
\hline $\begin{array}{l}\text { (Obeid et al, } \\
\text { 2016) }\end{array}$ & 147 & $\begin{array}{l}\text { Expression of PD-L1 and PD-L2 correlated with increasing densities of immune cells. PD-L2 } \\
\text { expression associated with improved OS }\end{array}$ & $\begin{array}{l}\text { Positive } \\
\text { association }\end{array}$ & PD-L2 and TILs \\
\hline $\begin{array}{l}\text { (Weiss et al, } \\
\text { 2016) }\end{array}$ & 1241 & $\begin{array}{l}\text { Melanomas with brisk TILs are defined by an immunostimulatory gene expression profile } \\
\text { and improved prognosis compared with melanomas with non-brisk or absent TILs }\end{array}$ & $\begin{array}{l}\text { Positive } \\
\text { association }\end{array}$ & TILs \\
\hline $\begin{array}{l}\text { (Garg et al, } \\
\text { 2016) }\end{array}$ & 57 & $\begin{array}{l}\text { B cells are associated with a significantly better overall survival in patients with cutaneous } \\
\text { primary melanomas of }>1 \mathrm{~mm} \text { Breslow depth }\end{array}$ & $\begin{array}{l}\text { Positive } \\
\text { association }\end{array}$ & B cells \\
\hline $\begin{array}{l}\text { (Bosisio et al, } \\
\text { 2016) }\end{array}$ & 710 & $\begin{array}{l}\text { Sheets/clusters of plasma cells associated with worse prognosis than melanomas without } \\
\text { plasma cells }\end{array}$ & $\begin{array}{l}\text { Negative } \\
\text { association }\end{array}$ & Plasma cells \\
\hline $\begin{array}{l}\text { (Messaoudene } \\
\text { et al, 2015) }\end{array}$ & 39 & $\begin{array}{l}\text { NK cells in SLN associated with higher risk of relapse; NK cells did not correlate with } \\
\text { thickness of primary but with patient age }\end{array}$ & $\begin{array}{l}\text { Negative } \\
\text { association }\end{array}$ & NK cells \\
\hline $\begin{array}{l}\text { (Fortes et al, } \\
\text { 2015) }\end{array}$ & 4133 & High levels TILs associated with improved OS & $\begin{array}{l}\text { Positive } \\
\text { association }\end{array}$ & TIL \\
\hline $\begin{array}{l}\text { (Song et al, } \\
\text { 2015) }\end{array}$ & 82 & TILs decreased the risk of distant metastases in oral mucosal melanoma & $\begin{array}{l}\text { Positive } \\
\text { association }\end{array}$ & TIL \\
\hline $\begin{array}{l}\text { (Donizy et al, } \\
\text { 2015) }\end{array}$ & 104 & High levels TILs associated with improved OS & $\begin{array}{l}\text { Positive } \\
\text { association }\end{array}$ & TIL \\
\hline $\begin{array}{l}\text { (Eriksson et al, } \\
\text { 2015) }\end{array}$ & 4237 & TILs demonstrated no prognostic value for survival & $\begin{array}{l}\text { No } \\
\text { association }\end{array}$ & TIL \\
\hline $\begin{array}{l}\text { (Thomas et al, } \\
\text { 2013) }\end{array}$ & 3330 & High levels TILs associated with improved OS & $\begin{array}{l}\text { Positive } \\
\text { association }\end{array}$ & TIL \\
\hline $\begin{array}{l}\text { (Cintolo et al, } \\
\text { 2013) }\end{array}$ & 161 & $\begin{array}{l}\text { Absence of TIL was associated with worse DSS; In radial growth phase presence of TIL with } \\
\text { regression was associated with a poor prognosis }\end{array}$ & $\begin{array}{l}\text { Positive } \\
\text { association }\end{array}$ & TIL \\
\hline $\begin{array}{l}\text { (Lee et al, } \\
\text { 2013) }\end{array}$ & 90 & Brisk TILs were associated with improved prognosis in acral melanoma & $\begin{array}{l}\text { Positive } \\
\text { association }\end{array}$ & TIL \\
\hline $\begin{array}{l}\text { (Grotz et al, } \\
\text { 2013) }\end{array}$ & 250 & $\begin{array}{l}\text { TILs in elderly melanoma patients predicts both SLN metastasis and improved melanoma- } \\
\text { specific outcomes }\end{array}$ & $\begin{array}{l}\text { Positive } \\
\text { association }\end{array}$ & TIL \\
\hline $\begin{array}{l}\text { (Azimi et al, } \\
\text { 2012) }\end{array}$ & 1865 & $\begin{array}{l}\text { TIL grade is an independent predictor of OS. Pronounced TIL infiltrate associated with } \\
\text { excellent prognosis }\end{array}$ & $\begin{array}{l}\text { Positive } \\
\text { association }\end{array}$ & TIL \\
\hline $\begin{array}{l}\text { (Erdag et al, } \\
\text { 2012) }\end{array}$ & 147 & $\begin{array}{l}\text { Higher densities of CD8 + T cells correlated best with survival, a higher density of CD45 + } \\
\text { leukocytes, T cells, and B cells also correlated with increased survival }\end{array}$ & $\begin{array}{l}\text { Positive } \\
\text { association }\end{array}$ & $\begin{array}{l}\text { CD8, CD45, T } \\
\text { cells and B cells }\end{array}$ \\
\hline $\begin{array}{l}\text { (Ladanyi et al, } \\
\text { 2011) }\end{array}$ & 106 & $\begin{array}{l}\text { CD20 + B cells most often found in peritumoural stroma, correlated with activated T } \\
\text { lymphocytes and high number of these cells provided OS advantage }\end{array}$ & $\begin{array}{l}\text { Positive } \\
\text { association }\end{array}$ & $\begin{array}{l}\text { CD20 B cells and } \\
\text { activated } T \text { cells }\end{array}$ \\
\hline $\begin{array}{l}\text { (Knol et al, } \\
2011)\end{array}$ & 102 & $\begin{array}{l}\text { High Foxp3 expression using qPCR predicts for worse progression free survival in stage III } \\
\text { melanoma patients }\end{array}$ & $\begin{array}{l}\text { Negative } \\
\text { association }\end{array}$ & FOXP3 \\
\hline $\begin{array}{l}\text { (Burton et al, } \\
\text { 2011) }\end{array}$ & 515 & $\begin{array}{l}\text { TIL response is a significant predictor of SLN metastasis but is not a major predictor of DFS } \\
\text { or OS }\end{array}$ & $\begin{array}{l}\text { No } \\
\text { association }\end{array}$ & TIL \\
\hline
\end{tabular}


Table 4. Immune cells in renal cell carcinoma

\begin{tabular}{|c|c|c|c|c|}
\hline Study & $\begin{array}{l}\text { Number } \\
\text { patients }\end{array}$ & Result & Association & Cell type \\
\hline $\begin{array}{l}\text { (Geissler } \\
\text { et al, 2015) }\end{array}$ & 104 & $\begin{array}{l}\text { Tumour-infiltrating NK cells and Th1 markers associated with increased OS, for example, } \\
\text { HLA-DRC and CXCR3C T cells; whereas a high number of T cells, especially with high } \\
\text { CD69 expression correlated with worse prognosis }\end{array}$ & $\begin{array}{l}\text { Positive association; } \\
\text { negative association }\end{array}$ & $\begin{array}{l}\text { NK and Th1; T } \\
\text { cells (CD69) }\end{array}$ \\
\hline $\begin{array}{l}\text { (Kang et al, } \\
\text { 2013) }\end{array}$ & 199 & PD1-positive or FoxP3-positive lymphocytes predicted poor OS survival & Negative association & $\begin{array}{l}\text { FOXP3, } \\
\text { PD1 }+ \\
\text { lymphocytes }\end{array}$ \\
\hline $\begin{array}{l}\text { (Hotta } \\
\text { et al, 2015) }\end{array}$ & 105 & Low levels of memory $T$ cells had improved OS & Negative association & $\begin{array}{l}\text { Memory } \mathrm{T} \\
\text { cells }\end{array}$ \\
\hline $\begin{array}{l}(\text { Eckl et al, } \\
\text { 2012) }\end{array}$ & 41 & NK cell percentage does not provide prognostic information & No association & NK cells \\
\hline $\begin{array}{l}\text { (Liotta } \\
\text { et al, 2011) }\end{array}$ & 30 & Increase in both peripheral and intratumoural Tregs associated with worse prognosis & Negative association & Tregs \\
\hline $\begin{array}{l}(\text { Li et al, } \\
2009)\end{array}$ & 125 & $\begin{array}{l}\text { Increased peritumoural Tregs are associated with worse prognosis in clear cell renal cell } \\
\text { carcinoma }\end{array}$ & Negative association & Tregs \\
\hline $\begin{array}{l}\text { (Bromwich } \\
\text { et al, 2003) }\end{array}$ & 73 & $\begin{array}{l}\text { Increased CD4 + T cells associated with worse cancer-specific survival; no association } \\
\text { demonstrated with CD8 }+T \text { cells }\end{array}$ & Negative association & CD4 \\
\hline
\end{tabular}

\section{Table 5. Studies of TILs in head and neck squamous cell carcinoma}

\begin{tabular}{|c|c|c|c|c|}
\hline Study & $\begin{array}{l}\text { Number } \\
\text { patients }\end{array}$ & Result & Association & Cell type \\
\hline $\begin{array}{l}\text { (Xu et al, } \\
2017)\end{array}$ & 202 & TIL level was an independent positive prognostic factor for DFS & $\begin{array}{l}\text { Positive } \\
\text { association }\end{array}$ & TIL \\
\hline $\begin{array}{l}\text { (Kogashiwa } \\
\text { et al, 2017) }\end{array}$ & 84 & $\begin{array}{l}\text { PD-L1 expression was associated with CD8 + tumour-infiltrating lymphocytes and } \\
\text { better outcome in patients with locally advanced oropharyngeal SCC }\end{array}$ & $\begin{array}{l}\text { Positive } \\
\text { association }\end{array}$ & CD8 \\
\hline $\begin{array}{l}\text { (Punt et al, } \\
\text { 2016) }\end{array}$ & 162 & $\begin{array}{l}\text { High number of T cells was correlated with improved DFS in HPV-positive } \\
\text { oropharyngeal SCC; improved outcome correlated with active Th17 cells and lower } \\
\mathrm{IL}-17(+) \text { non-T cells }\end{array}$ & $\begin{array}{l}\text { Positive } \\
\text { association }\end{array}$ & T cells, Th17 \\
\hline $\begin{array}{l}\text { (Nguyen } \\
\text { et al, 2016) }\end{array}$ & 278 & Higher CD4 levels predicted improved OS and disease-specific survival & $\begin{array}{l}\text { Positive } \\
\text { association }\end{array}$ & CD4 \\
\hline $\begin{array}{l}\text { (Caldeira } \\
\text { et al, 2015) }\end{array}$ & 28 & $\begin{array}{l}\text { Increased neutrophilic infiltration demonstrated in tumours with higher T stage; no } \\
\text { correlation with survival }\end{array}$ & No association & Neutrophils \\
\hline $\begin{array}{l}\text { (Balermpas } \\
\text { et al, } \\
2016 b)\end{array}$ & 161 & $\begin{array}{l}\text { CD8 + TILs constitute an independent prognostic marker in HNSCC patients treated } \\
\text { with adjuvant chemoradiotherapy; prognostic benefit is apparent in HPV pos and neg } \\
\text { subgroups }\end{array}$ & $\begin{array}{l}\text { Positive } \\
\text { association }\end{array}$ & CD8 \\
\hline $\begin{array}{l}\text { (Partlova } \\
\text { et al, 2015) }\end{array}$ & 54 & $\begin{array}{l}\text { HPV-positive tumour showed significantly higher numbers of infiltrating IFN } \gamma+ \\
\text { CD } 8+\text { T lymphocytes, IL-17 }+ \text { CD } 8+\text { T lymphocytes, myeloid dendritic cells and are } \\
\text { associated with better outcome compared to HPV-negative }\end{array}$ & $\begin{array}{l}\text { Positive } \\
\text { association }\end{array}$ & $\begin{array}{l}\text { IFN } \gamma+\mathrm{CD} 8+\mathrm{T} \\
\text { cells, IL-17 CD } 8+\mathrm{T} \\
\text { cells }\end{array}$ \\
\hline $\begin{array}{l}\text { (Wolf et al, } \\
\text { 2015) }\end{array}$ & 39 & $\begin{array}{l}\text { CD68 + macrophages were found associated with positive nodes and poorer overall } \\
\text { survival (not significant) }\end{array}$ & $\begin{array}{l}\text { Negative } \\
\text { association }\end{array}$ & Macrophages \\
\hline $\begin{array}{l}\text { (Ward et al, } \\
\text { 2014) }\end{array}$ & 270 & TIL levels prognostic in HPV-positive HNSCC & $\begin{array}{l}\text { Positive } \\
\text { association }\end{array}$ & TIL \\
\hline $\begin{array}{l}\text { (Balermpas } \\
\text { et al, 2014) }\end{array}$ & 101 & $\begin{array}{l}\text { High infiltrating } C D 3+\text { and } C D 8+\text { cells correlate with survival outcomes with } \\
\text { chemoradiation }\end{array}$ & $\begin{array}{l}\text { Positive } \\
\text { association }\end{array}$ & $\begin{array}{l}\mathrm{CD} 3+\text { and } \mathrm{CD} 8+\mathrm{T} \\
\text { cells }\end{array}$ \\
\hline $\begin{array}{l}\text { (Nordfors } \\
\text { et al, 2013) }\end{array}$ & 203 & $\begin{array}{l}\text { Higher CD8 }(+) \text { TIL counts correlated to a better 3-year OS in HPV pos; no correlation } \\
\text { of CD4 }(+) \text { TILs with survival outcomes }\end{array}$ & $\begin{array}{l}\text { Positive } \\
\text { association; no } \\
\text { association }\end{array}$ & CD8; CD4 \\
\hline $\begin{array}{l}\text { (Fraga et al, } \\
\text { 2012) }\end{array}$ & 70 & CD57 + TILs do not correlate with survival outcomes & No association & CD57 \\
\hline $\begin{array}{l}\text { (Wansom } \\
\text { et al, 2012) }\end{array}$ & 46 & $\begin{array}{l}\text { T-cell infiltration did not differ by HPV status; related to DSS and OS; after adjusting } \\
\text { for HPV status, CD8, FoxP3, and total T cells were significantly associated with DSS } \\
\text { and OS }\end{array}$ & $\begin{array}{l}\text { Positive } \\
\text { association }\end{array}$ & $\begin{array}{l}\text { CD8, FOXP3 and } \\
\text { total T cells }\end{array}$ \\
\hline $\begin{array}{l}\text { (Sun et al, } \\
\text { 2012) }\end{array}$ & 83 & $\begin{array}{l}\text { Tumour-infiltrating CD4 }+ \text { CD25(high) Foxp } 3+\text { Tregs correlated with intratumoural } \\
\text { COX-2 expression and were associated with a worse recurrence free survival in } \\
\text { univariate but not multivariate analysis }\end{array}$ & No association & FOXP3 \\
\hline $\begin{array}{l}\text { (Pretscher } \\
\text { et al, 2009) }\end{array}$ & 33 & $\begin{array}{l}\text { Intra-epithelial CD8 cells in metastatic lymph nodes and high CD20 + B cells in } \\
\text { lymphoid tissue of lymph node metastases were associated with improved DFS }\end{array}$ & $\begin{array}{l}\text { Positive } \\
\text { association }\end{array}$ & CD8, B cells \\
\hline $\begin{array}{l}\text { (Badoual, } \\
\text { 2006) }\end{array}$ & 84 & CD4 + CD69 + T cells are associated with improved OS & $\begin{array}{l}\text { Positive } \\
\text { association }\end{array}$ & CD4CD69+ T cells \\
\hline
\end{tabular}


between stromal CD4-expressing cells and outcome was not observed (HR 0.43; 95\% CI: $0.07-2.61, P=0.36$ ), likely due to greater heterogeneity. FOXP3-expressing $\mathrm{T}$ cells in the tumour stroma had association with worse progression-free and OS (HR: 2.14; 95\% CI: $1.68-2.72 ; P<0.001)$ and 2.67 (95\% CI: 1.74-4.08; $P<0.001$, respectively) (Geng et al, 2015).

Melanoma. Checkpoint inhibitors were first approved in melanoma after a long history of interest in the immune response to these tumours after observation of spontaneous responses (Mihm and Mule, 2015). One histopathological definition of the immune response in melanoma categorised the immune infiltrating response as 'brisk', a scenario where lymphocytes are demonstrated in the entire tumour mass or along the advancing edge; 'non-brisk', where lymphocytes are seen focally in the centre of the tumour or along part of the invasive margin; or 'absent' with no tumoural lymphocytes at all or lymphocytes seen, but not interacting with melanoma cells. These subgroups provide prognostic information in historical studies. In one study, melanoma-specific death was 30 and $50 \%$ lower in the non-brisk and brisk groups, respectively, compared with the absent group (Mihm and Mule, 2015). In contrast, studies report no survival advantage with lymphocytic infiltrate particularly with respect to tumours of earlier stage and not in the radial growth phase (Ladanyi, 2015). However, overall, there is a large body of evidence documenting the prognostic value of the immune infiltrate in melanoma (see summary in Table 3).

Renal cell carcinoma. There is contradictory evidence regarding the role of the immune cell infiltrate in renal cell carcinoma. Multiple studies have demonstrated a worse outcome in patients with a neutrophilic, and/or lymphocytic infiltrate (Jochems and Schlom, 2011), a finding which appears reproducible (Table 4). The reasons for this are not clear.

Head and neck cancer. Several clinical trials have demonstrated that tumour infiltration by CD3- and CD8-expressing T cells correlates with improved disease outcome in chemoradiotherapy-treated patients with head and neck cancer. This positive prognosis holds true regardless of the human papilloma virus (HPV) DNA status (Balermpas et al, 2016a). Smoking-associated tumours with higher degrees of genomic instability and higher antigenicity would be expected to have increased potential to activate an immune response; however, this is not supported by clinical evidence. There is conflicting information regarding differences in the immune infiltrate in HPV-positive vs negative status (Wansom et al, 2012; Partlova et al, 2015); see Table 5.
Urothelial cancers. The approval of immunotherapy in the treatment of advanced urothelial malignancy suggests the relevance of the immune system. This is supported by most studies demonstrating the positive prognostic value of CD3, CD4 and CD8 T cells, and the negative association of FOXP3-positive T cells with survival, see Table 6 .

Hepatocellular carcinoma. Several studies have examined the role of the intratumoural and peritumoural (parenchymal) infiltrate in hepatocellular carcinoma (HCC) (Table 7). High levels of FOXP3 Tregs are associated with worse DFS and OS. Two large meta-analyses performed in 2014 demonstrate the importance of FOXP3 in both the development and prognosis of HCC (Huang et al, 2014; Zhao et al, 2014). Gabrielson et al, 2016 applied the Galon Immunoscore (Galon et al, 2014) to HCC and confirmed its prognostic value, CD3 and CD8 cell densities predicted recurrence with ORs of 5.8 (95\% CI: 1.6-21.8) and 3.9 (95\% CI: 1.1-14.2), respectively. PDL1 staining was positively correlated with high CD3 and CD8 density and predicted a lower rate of recurrence (Gabrielson et al, 2016). The applicability of these tools remains limited by routine access to technology to subtype these $\mathrm{T}$ cells.

Other tumour types. The prognostic role of the immune infiltrate in less common malignancies is summarised in the Online Appendix.

\section{BRAIN METASTASES}

Although the central nervous system (CNS) has been purported to be an 'immune privileged' site, there is an increasing evidence supporting the role of immune infiltrating cells in brain tumours. In a study by Harter et al, TILs in brain metastases from different tumour types were quantified and associated with outcome. This was then validated in a breast cancer only brain metastases cohort. Carcinomas demonstrated more frequent stromal infiltration, whereas TILs in melanoma were more often diffusely infiltrative. High TILs level, high-programed cell death protein (PD) $1+/ \mathrm{CD} 8+$ and programed death ligand (PDL)-1 staining were associated with smaller tumours but there was no significant association with survival demonstrated (Harter et al, 2015). In contrast, Bienkowski and Preusser, 2015 provide a review of the literature in which they concluded that tumour-infiltrating lymphocyte density in CNS metastases were strongly associated with improved OS .

\section{Table 6. Studies examining prognostic impact of immune cells in bladder cancer}

\begin{tabular}{|c|c|c|c|c|}
\hline Study & $\begin{array}{l}\text { Number } \\
\text { patients }\end{array}$ & Result & Association & Cell type \\
\hline $\begin{array}{l}\text { (Krpina et al, } \\
\text { 2015) }\end{array}$ & 115 & $\begin{array}{l}\text { CD3 + and CD8 + TIL are predictive of bladder cancer recurrence in patients with } \\
\text { solitary low-grade non-muscle invasive bladder cancer }\end{array}$ & Positive association & CD3 and CD8 \\
\hline $\begin{array}{l}\text { (Wang et al, } \\
\text { 2015) }\end{array}$ & 302 & $\begin{array}{l}\text { Intratumoural CD103(+) TILs inversely associated with tumour size. High CD103 + cells } \\
\text { associated with improved OS. }\end{array}$ & Positive association & CD103+ \\
\hline $\begin{array}{l}\text { (Zhang et al, } \\
\text { 2015) }\end{array}$ & 131 & $\begin{array}{l}\text { Tumour-infiltrating CD4 }(+) \text { T cell density emerged as an independent prognostic factor } \\
\text { for OS (HR: } 2.75 ; P=0.004)\end{array}$ & Positive association & CD4 \\
\hline $\begin{array}{l}\text { Knief et al } \\
(2016)\end{array}$ & 149 & $\begin{array}{l}\text { FOXP3/CD8 (OS: } P=0.013, \mathrm{HR}: 1.32,95 \% \mathrm{Cls}: 1.06-1.65) \text { ratios were significantly } \\
\text { associated with briefer } \mathrm{OS} \text { and time to cancer-specific death }\end{array}$ & Negative association & $\begin{array}{l}\text { FOXP3/CD8 } \\
\text { ratio }\end{array}$ \\
\hline $\begin{array}{l}\text { (Sjodahl et al, } \\
\text { 2014) }\end{array}$ & 296 & $\begin{array}{l}\text { CD3 }(+) \text { TILs was significantly associated with good prognosis. Positive association with } \\
\text { CD3 was modulated by CD68 }(+) \text { TAMs. Strongest negative association with survival was } \\
\text { a high ratio between CD68 and CD3 }\end{array}$ & $\begin{array}{l}\text { Positive association; } \\
\text { Negative association }\end{array}$ & $\begin{array}{l}\mathrm{CD} 3+; \text { High } \\
\text { CD68/CD3 ratio }\end{array}$ \\
\hline $\begin{array}{l}\text { (Sharma et al, } \\
\text { 2007) }\end{array}$ & 69 & Higher numbers of CD8 TILs within the tumour $(>$ or $=8$ ) had better DFS and OS & Positive association & CD8 \\
\hline $\begin{array}{l}\text { (Hilmy et al, } \\
\text { 2006) }\end{array}$ & 103 & No correlation between TIL level and prognosis & No association & TILs \\
\hline
\end{tabular}


Table 7. Studies examining prognostic value in HCC

\begin{tabular}{|c|c|c|c|c|}
\hline Study & $\begin{array}{l}\text { Number } \\
\text { patients }\end{array}$ & Result & Association & Cell type \\
\hline $\begin{array}{l}\text { (Sideras } \\
\text { et al, 2017) }\end{array}$ & 154 & Low CD8 + TIL associated with poor HCC-specific survival. & $\begin{array}{l}\text { Positive } \\
\text { association }\end{array}$ & CD8 \\
\hline $\begin{array}{l}\text { (Gabrielson } \\
\text { et al, 2016) }\end{array}$ & 65 & $\begin{array}{l}\text { Intratumoural and peri-tumoural } C D 3+/ C D 8+\text { density associated with lower risk of } \\
\text { recurrence }\end{array}$ & $\begin{array}{l}\text { Positive } \\
\text { association }\end{array}$ & $\mathrm{CD} 3 / \mathrm{CD} 8$ ratio \\
\hline $\begin{array}{l}\text { (Tu et al, } \\
\text { 2016) }\end{array}$ & 57 & FOXP3 + Tregs/CD4 + T cells ratio was an independent prognostic factor for OS & $\begin{array}{l}\text { Positive } \\
\text { association }\end{array}$ & FOXP3/CD4 ratio \\
\hline $\begin{array}{l}\text { (Wang et al, } \\
\text { 2016) }\end{array}$ & 66 & $\begin{array}{l}\text { Tumour CD4 and CD8 lower than non-neoplastic liver; high Foxp3 associated with poor } \\
\text { OS, whereas low CD8 expression in non-neoplastic liver associated with high HCC } \\
\text { recurrence rate. }\end{array}$ & $\begin{array}{l}\text { Negative } \\
\text { association }\end{array}$ & FOXP3 \\
\hline $\begin{array}{l}\text { (He et al, } \\
\text { 2015) }\end{array}$ & 149 & $\begin{array}{l}\text { High neutrophil to lymphocyte ratio in peritumoural tissues correlated with poor } \\
\text { prognosis in patients with HCC }\end{array}$ & $\begin{array}{l}\text { Negative } \\
\text { association }\end{array}$ & $\begin{array}{l}\text { Neutrophil:lymphocyte } \\
\text { ratio }\end{array}$ \\
\hline $\begin{array}{l}\text { (Sun et al, } \\
\text { 2015) }\end{array}$ & 449 & CD8 + in tumour centre had highest prognostic impact on DFS and OS & $\begin{array}{l}\text { Positive } \\
\text { association }\end{array}$ & CD8 \\
\hline $\begin{array}{l}\text { (Ozgur et al, } \\
\text { 2014) }\end{array}$ & 8 & High FoxP3 + poorer DFS & $\begin{array}{l}\text { Negative } \\
\text { association }\end{array}$ & FOXP3 \\
\hline $\begin{array}{l}\text { (Brunner } \\
\text { et al, 2015) }\end{array}$ & 119 & IL-33 and CD8 + cells associated with prolonged OS & $\begin{array}{l}\text { Positive } \\
\text { association }\end{array}$ & IL-33 and CD8 \\
\hline $\begin{array}{l}\text { (Huang } \\
\text { et al, 2014) }\end{array}$ & 1964 & $\begin{array}{l}\text { OS significantly lower in high FOXP3 infiltrated tumours than low (at 1, } 3 \text { and } 5 \text { years) } \\
\text { (meta-analysis } 13 \text { studies) }\end{array}$ & $\begin{array}{l}\text { Positive } \\
\text { association }\end{array}$ & FOXP3 \\
\hline
\end{tabular}

Summary. Broadly speaking, the immune infiltrate can be classified as a 'pro-inflammatory' phenotype with infiltrating T cells and a cytokine profile consistent with immune activation. Immune control of tumours can occur spontaneously, and the presence of an immune infiltrate is generally a good prognostic sign. However, the immune infiltrate has variable effect in prognostic models depending on the tumour type, location of the cells and state of activation; the complexity of immune networks are likely oversimplified in current measurement models. Tumour evasion through inhibitory mechanisms may serve as a predictive marker for benefit from immunotherapy, which inhibits negative regulators of the immune system. Alternatively, the microenvironment may lack immune cell infiltration, and tumour resistance is likely through immune system ignorance (Gajewski et al, 2013), and therefore promoting immune activation is less likely to be successful in this setting.

For tumour-infiltrating immune cells to live up to the 'hype' of inducing and promoting long-term tumour control and contribute as valuable prognostic markers, their subtype (especially activated antigen specific cytotoxic $\mathrm{T}$ lymphocytes) and position (organised spatial response) need to be defined and measured in a standardised manner. Successful inclusion of immune cell markers in prognostic clinical models is becoming a realistic hope in some cancers.

\section{CONFLICT OF INTEREST}

The authors declare no conflict of interest.

\section{REFERENCES}

Adams S, Gray RJ, Demaria S, Goldstein L, Perez EA, Shulman LN, Martino S, Wang M, Jones VE, Saphner TJ, Wolff AC, Wood WC, Davidson NE, Sledge GW, Sparano JA, Badve SS (2014) Prognostic value of tumorinfiltrating lymphocytes in triple-negative breast cancers from two phase III randomized adjuvant breast cancer trials: ECOG 2197 and ECOG 1199. J Clin Oncol 32(27): 2959-2966.

Azimi F, Scolyer RA, Rumcheva P, Moncrieff M, Murali R, McCarthy SW, Saw RP, Thompson JF (2012) Tumor-infiltrating lymphocyte grade is an independent predictor of sentinel lymph node status and survival in patients with cutaneous melanoma. J Clin Oncol 30(21): 2678-2683.
Badoual C (2006) Prognostic value of tumor-infiltrating CD4 + T-cell subpopulations in head and neck cancers. Clin Cancer Res 12: 465-472.

Balermpas P, Michel Y, Wagenblast J, Seitz O, Weiss C, Rodel F, Rodel C, Fokas E (2014) Tumour-infiltrating lymphocytes predict response to definitive chemoradiotherapy in head and neck cancer. Br J Cancer 110(2): 501-509.

Balermpas P, Rödel F, Rödel C, Krause M, Linge A, Lohaus F, Baumann M, Tinhofer I, Budach V, Gkika E, Stuschke M, Avlar M, Grosu A-L, Abdollahi A, Debus J, Bayer C, Stangl S, Belka C, Pigorsch S, Multhoff G, Combs SE, Mönnich D, Zips D, Fokas E (2016a) CD8 + tumourinfiltrating lymphocytes in relation to HPV status and clinical outcome in patients with head and neck cancer after postoperative chemoradiotherapy: a multicentre study of the German cancer consortium radiation oncology group (DKTK-ROG). Int J Cancer 138(1): 171-181.

Balermpas P, Rodel F, Rodel C, Krause M, Linge A, Lohaus F, Baumann M, Tinhofer I, Budach V, Gkika E, Stuschke M, Avlar M, Grosu AL, Abdollahi A, Debus J, Bayer C, Stangl S, Belka C, Pigorsch S, Multhoff G, Combs SE, Monnich D, Zips D, Fokas E (2016b) CD8 + tumourinfiltrating lymphocytes in relation to HPV status and clinical outcome in patients with head and neck cancer after postoperative chemoradiotherapy: a multicentre study of the German cancer consortium radiation oncology group (DKTK-ROG). Int J Cancer 138(1): 171-181.

Bienkowski M, Preusser M (2015) Prognostic role of tumour-infiltrating inflammatory cells in brain tumours: literature review. Curr Opin Neurol 28(6): 647-658.

Bosisio FM, Wilmott JS, Volders N, Mercier M, Wouters J, Stas M, Blokx WAM, Massi D, Thompson JF, Scolyer RA, van Baren N, van den Oord JJ (2016) Plasma cells in primary melanoma. Prognostic significance and possible role of IgA. Mod Pathol 29(4): 347-358.

Bromwich EJ, McArdle PA, Canna K, McMillan DC, McNicol A, Brown M, Aitchison M (2003) The relationship between T-lymphocyte infiltration, stage, tumour grade and survival in patients undergoing curative surgery for renal cell cancer. Br J Cancer 89(10): 1906-1908.

Brunner SM, Rubner C, Kesselring R, Martin M, Griesshammer E, Ruemmele P, Stempfl T, Teufel A, Schlitt HJ, Fichtner-Feigl S (2015) Tumor-infiltrating, interleukin-33-producing effector-memory CD8(+) $\mathrm{T}$ cells in resected hepatocellular carcinoma prolong patient survival. Hepatology 61(6): 1957-1967.

Burton AL, Roach BA, Mays MP, Chen AF, Ginter BA, Vierling AM, Scoggins CR, Martin RC, Stromberg AJ, Hagendoorn L, McMasters KM (2011) Prognostic significance of tumor infiltrating lymphocytes in melanoma. Am Surg 77(2): 188-192.

Caldeira PC, de Andrade Sousa A, de Aguiar MC (2015) Differential infiltration of neutrophils in T1-T2 versus T3-T4 oral squamous cell carcinomas: a preliminary study. BMC Res Notes 8: 569. 
Cintolo JA, Gimotty P, Blair A, Guerry D, Elder DE, Hammond R, Elenitsas R, Xu X, Fraker D, Schuchter LM, Czerniecki BJ, Karakousis G (2013) Local immune response predicts survival in patients with thick (t4) melanomas. Ann Surg Oncol 20(11): 3610-3617.

Denkert C, Gv Minckwitz, Brase JC, Sinn BV, Gade S, Kronenwett R, Pfitzner BM, Salat C, Loi S, Schmitt WD, Schem C, Fisch K, Darb-Esfahani S, Mehta K, Sotiriou C, Wienert S, Klare P, André F, Klauschen F, Blohmer J-U, Krappmann K, Schmidt M, Tesch H, Kümmel S, Sinn P, Jackisch C, Dietel M, Reimer T, Untch M, Loibl S (2015) Tumor-infiltrating lymphocytes and response to neoadjuvant chemotherapy with or without carboplatin in human epidermal growth factor receptor 2-positive and triple-negative primary breast cancers. J Clin Oncol 33(9): 983-991.

Donizy P, Kaczorowski M, Halon A, Leskiewicz M, Kozyra C, Matkowski R (2015) Paucity of tumor-infiltrating lymphocytes is an unfavorable prognosticator and predicts lymph node metastases in cutaneous melanoma patients. Anticancer Res 35(1): 351-358.

Dushyanthen S, Beavis PA, Savas P, Teo ZL, Zhou C, Mansour M, Darcy PK, Loi S (2015) Relevance of tumor-infiltrating lymphocytes in breast cancer. BMC Med 13: 202.

Eckl J, Buchner A, Prinz PU, Riesenberg R, Siegert SI, Kammerer R, Nelson PJ, Noessner E (2012) Transcript signature predicts tissue NK cell content and defines renal cell carcinoma subgroups independent of TNM staging. J Mol Med 90(1): 55-66.

Engels B, Engelhard Victor H, Sidney J, Sette A, Binder David C, Liu Rebecca B, Kranz David M, Meredith Stephen C, Rowley Donald A, Schreiber H (2013) Relapse or eradication of cancer is predicted by peptide-major histocompatibility complex affinity. Cancer Cell 23(4): 516-526.

Erdag G, Schaefer JT, Smolkin ME, Deacon DH, Shea SM, Dengel LT, Patterson JW, Slingluff CL (2012) Immunotype and immunohistologic characteristics of tumor infiltrating immune cells are associated with clinical outcome in metastatic melanoma. Cancer Res 72(5): 1070-1080.

Eriksson H, Frohm-Nilsson M, Järås J, Kanter-Lewensohn L, Kjellman P, Månsson-Brahme E, Vassilaki I, Hansson J (2015) Prognostic factors in localized invasive primary cutaneous malignant melanoma: results of a large population-based study. Br J Dermatol 172(1): 175-186.

Fortes C, Mastroeni S, Mannooranparampil TJ, Passarelli F, Zappala A, Annessi G, Marino C, Caggiati A, Russo N, Michelozzi P (2015) Tumorinfiltrating lymphocytes predict cutaneous melanoma survival. Melanoma Res 25(4): 306-311.

Fraga CA, de Oliveira MV, Domingos PL, Botelho AC, Guimaraes AL, Teixeira-Carvalho A, Correa-Oliveira R, De Paula AM (2012) Infiltrating CD57 + inflammatory cells in head and neck squamous cell carcinoma: clinicopathological analysis and prognostic significance. Appl Immunohistochem Mol Morphol 20(3): 285-290.

Fridman WH, Galon J, Pagès F, Tartour E, Sautès-Fridman C, Kroemer G (2011) Prognostic and Predictive Impact of Intra- and Peritumoral Immune Infiltrates. Cancer Res 71(17): 5601-5605.

Gabrielson A, Wu Y, Wang H, Jiang J, Kallakury B, Gatalica Z, Reddy S, Kleiner D, Fishbein T, Johnson L, Island E, Satoskar R, Banovac F, Jha R, Kachhela J, Feng P, Zhang T, Tesfaye A, Prins P, Loffredo C, Marshall J, Weiner L, Atkins M, He AR (2016) Intratumoral CD3 and CD8 T-cell densities associated with relapse-free survival in HCC. Cancer Immunol Res 4(5): 419-430.

Gajewski TF, Schreiber H, Fu Y-X (2013) Innate and adaptive immune cells in the tumor microenvironment. Nat Immunol 14(10): 1014-1022.

Galon J, Mlecnik B, Bindea G, Angell HK, Berger A, Lagorce C (2014) Towards the introduction of the 'Immunoscore' in the classification of malignant tumours. J Pathol 232: 199-209.

Garg K, Maurer M, Griss J, Bruggen MC, Wolf IH, Wagner C, Willi N, Mertz KD, Wagner SN (2016) Tumor-associated B cells in cutaneous primary melanoma and improved clinical outcome. Hum Pathol 54: $157-164$.

Geissler K, Fornara P, Lautenschlager C, Holzhausen HJ, Seliger B, Riemann D (2015) Immune signature of tumor infiltrating immune cells in renal cancer. Oncoimmunology 4(1): e985082.

Geng Y, Shao Y, He W, Hu W, Xu Y, Chen J, Wu C, Jiang J (2015) Prognostic role of tumor-infiltrating lymphocytes in lung cancer: a meta-analysis. Cell Physiol Biochem 37(4): 1560-1571.

Grotz TE, Vaince F, Hieken TJ (2013) Tumor-infiltrating lymphocyte response in cutaneous melanoma in the elderly predicts clinical outcomes. Melanoma Res 23(2): 132-137.
Hanahan D, Weinberg RA (2011) Hallmarks of cancer: the next generation. Cell 144(5): 646-674.

Harter PN, Bernatz S, Scholz A, Zeiner PS, Zinke J, Kiyose M, Blasel S, Beschorner R, Senft C, Bender B, Ronellenfitsch MW, Wikman H, Glatzel M, Meinhardt M, Juratli TA, Steinbach JP, Plate KH, Wischhusen J, Weide B, Mittelbronn M (2015) Distribution and prognostic relevance of tumor-infiltrating lymphocytes (TILs) and PD-1/PD-L1 immune checkpoints in human brain metastases. Oncotarget 6(38): 40836-40849.

He G, Zhang H, Zhou J, Wang B, Chen Y, Kong Y, Xie X, Wang X, Fei R, Wei L, Chen H, Zeng H (2015) Peritumoural neutrophils negatively regulate adaptive immunity via the PD-L1/PD-1 signalling pathway in hepatocellular carcinoma. J Exp Clin Cancer Res 34: 141.

Hilmy M, Campbell R, Bartlett JMS, McNicol AM, Underwood MA, McMillan DC (2006) The relationship between the systemic inflammatory response, tumour proliferative activity, T-lymphocytic infiltration and COX-2 expression and survival in patients with transitional cell carcinoma of the urinary bladder. Br J Cancer 95(9): 1234-1238.

Hotta K, Kato Y, Leighl N, Takigawa N, Gaafar RM, Kayatani H, Hirata T, Ohashi K, Kubo T, Tabata M, Tanimoto M, Kiura K (2015) Magnitude of the benefit of progression-free survival as a potential surrogate marker in phase 3 trials assessing targeted agents in molecularly selected patients with advanced non-small cell lung cancer: systematic review. PLoS One 10(3): e0121211.

Huang Y, Liao H, Zhang Y, Yuan R, Wang F, Gao Y, Wang P, Du Z (2014) Prognostic value of tumor-infiltrating FoxP3 $+\mathrm{T}$ cells in gastrointestinal cancers: a meta analysis. PLoS ONE 9(5): e94376.

Hwang W-T, Adams SF, Tahirovic E, Hagemann IS, Coukos G (2012) Prognostic significance of tumor-infiltrating T-cells in ovarian cancer: a meta-analysis. Gynecol Oncol 124(2): 192-198.

Jochems C, Schlom J (2011) Tumor-infiltrating immune cells and prognosis: the potential link between conventional cancer therapy and immunity. Exp Biol Med 236(5): 567-579.

Kakavand H, Vilain RE, Wilmott JS, Burke H, Yearley JH, Thompson JF, Hersey P, Long GV, Scolyer RA (2015) Tumor PD-L1 expression, immune cell correlates and PD-1 + lymphocytes in sentinel lymph node melanoma metastases. Mod Pathol 28(12): 1535-1544.

Kang MJ, Kim KM, Bae JS, Park HS, Lee H, Chung MJ, Moon WS, Lee DG, Jang KY (2013) Tumor-infiltrating PD1-positive lymphocytes and FoxP3-positive regulatory $\mathrm{T}$ cells predict distant metastatic relapse and survival of clear cell renal cell carcinoma. Transl Oncol 6(3): 282-289.

Knief J, Reddemann K, Petrova E, Herhahn T, Wellner U, Thorns C (2016) High density of tumor-infiltrating B-lymphocytes and plasma cells signifies prolonged overall survival in adenocarcinoma of the esophagogastric junction. Anticancer Res 36(10): 5339-5345.

Knol AC, Nguyen JM, Quereux G, Brocard A, Khammari A, Dreno B (2011) Prognostic value of tumor-infiltrating Foxp3 + T-cell subpopulations in metastatic melanoma. Exp Dermatol 20(5): 430-434.

Kogashiwa Y, Yasuda M, Sakurai H, Nakahira M, Sano Y, Gonda K, Ikeda T, Inoue $\mathrm{H}$, Kuba K, Oba S, Ishikawa J, Enoki $\mathrm{Y}$, Matsumura S, Minami K, Ebihara Y, Sugasawa M (2017) PD-L1 expression confers better prognosis in locally advanced oral squamous cell carcinoma. Anticancer Res 37(3): 1417-1424.

Krpina K, Babarovic E, Jonjic N (2015) Correlation of tumor-infiltrating lymphocytes with bladder cancer recurrence in patients with solitary low-grade urothelial carcinoma. Virchows Archiv 467(4): 443-448.

Ladanyi A (2015) Prognostic and predictive significance of immune cells infiltrating cutaneous melanoma. Pigment Cell Melanoma Res 28(5): 490-500.

Ladanyi A, Kiss J, Mohos A, Somlai B, Liszkay G, Gilde K, Fejos Z, Gaudi I, Dobos J, Timar J (2011) Prognostic impact of B-cell density in cutaneous melanoma. Cancer Immunol Immunother 60(12): 1729-1738.

Lee S-J, Lim HJ, Choi YH, Chang YH, Lee WJ, Kim DW, Yoon GS (2013) The clinical significance of tumor-infiltrating lymphocytes and microscopic satellites in acral melanoma in a Korean population. Ann Dermatol 25(1): 61-66.

Li JF, Chu YW, Wang GM, Zhu TY, Rong RM, Hou J, Xu M (2009) The prognostic value of peritumoral regulatory $\mathrm{T}$ cells and its correlation with intratumoral cyclooxygenase-2 expression in clear cell renal cell carcinoma. BJU Int 103(3): 399-405.

Liotta F, Gacci M, Frosali F, Querci V, Vittori G, Lapini A, Santarlasci V, Serni S, Cosmi L, Maggi L, Angeli R, Mazzinghi B, Romagnani P, Maggi E, Carini M, Romagnani S, Annunziato F (2011) Frequency of regulatory T 
cells in peripheral blood and in tumour-infiltrating lymphocytes correlates with poor prognosis in renal cell carcinoma. BJU Int 107(9): 1500-1506.

Man Y-G, Stojadinovic A, Mason J, Avital I, Bilchik A, Bruecher B, Protic M, Nissan A, Izadjoo M, Zhang X, Jewett A (2013) Tumor-infiltrating immune cells promoting tumor invasion and metastasis: existing theories. $J$ Cancer 4(1): 84-95.

Mao Y, Qu Q, Chen X, Huang O, Wu J, Shen K (2016) The prognostic value of tumor-infiltrating lymphocytes in breast cancer: a systematic review and meta-analysis. PLOS ONE 11(4): e0152500.

Marvel D, Gabrilovich DI (2015) Myeloid-derived suppressor cells in the tumor microenvironment: expect the unexpected. J Clin Invest 125(9): 3356-3364.

Mei Z, Liu Y, Liu C, Cui A, Liang Z, Wang G, Peng H, Cui L, Li C (2014) Tumour-infiltrating inflammation and prognosis in colorectal cancer: systematic review and meta-analysis. Br J Cancer 110(6): 1595-1605.

Messaoudene M, Perier A, Fregni G, Neves E, Zitvogel L, Cremer I, Chanal J, Sastre-Garau X, Deschamps L, Marinho E, Larousserie F, Maubec E, Avril MF, Caignard A (2015) Characterization of the microenvironment in positive and negative sentinel lymph nodes from melanoma patients. PLoS One 10(7): e0133363.

Mihm Jr. MC, Mule JJ (2015) Reflections on the histopathology of tumorinfiltrating lymphocytes in melanoma and the host immune response. Cancer Immunol Res 3(8): 827-835.

Mittal D, Gubin MM, Schreiber RD, Smyth MJ (2014) New insights into cancer immunoediting and its three component phases-elimination, equilibrium and escape. Curr Opin Immunol 27: 16-25.

Nguyen N, Bellile E, Thomas D, McHugh J, Rozek L, Virani S, Peterson L, Carey TE, Walline H, Moyer J, Spector M, Perim D, Prince M, McLean S, Bradford CR, Taylor JM, Wolf GT (2016) Tumor infiltrating lymphocytes and survival in patients with head and neck squamous cell carcinoma. Head Neck 38(7): 1074-1084.

Nordfors C, Grun N, Tertipis N, Ahrlund-Richter A, Haeggblom L, Sivars L, Du J, Nyberg T, Marklund L, Munck-Wikland E, Nasman A, Ramqvist T, Dalianis T (2013) CD8 + and CD4 + tumour infiltrating lymphocytes in relation to human papillomavirus status and clinical outcome in tonsillar and base of tongue squamous cell carcinoma. Eur J Cancer 49(11): 2522-2530.

Obeid JM, Erdag G, Smolkin ME, Deacon DH, Patterson JW, Chen L, Bullock TN, Slingluff CL (2016) PD-L1, PD-L2 and PD-1 expression in metastatic melanoma: correlation with tumor-infiltrating immune cells and clinical outcome. Oncoimmunology 5(11): e1235107.

Ozgur HH, Ercetin AP, Eliyatkin N, Seren A, Kupelioglu A, Ortac R, Diniz G, Aktas S (2014) Regulatory T cells and their prognostic value in hepatopancreatobiliary tumours. Hepatogastroenterology 61(135): 1847-1851.

Park CK, Kim SK (2017) Clinicopathological significance of intratumoral and peritumoral lymphocytes and lymphocyte score based on the histologic subtypes of cutaneous melanoma. Oncotarget 8(9): 14759-14769.

Park JH, Roxburgh CS, McMillan DC (2014) Comment on 'Tumourinfiltrating inflammation and prognosis in colorectal cancer: systematic review and meta-analysis'. Br J Cancer 111(12): 2372.

Partlova S, Boucek J, Kloudova K, Lukesova E, Zabrodsky M, Grega M, Fucikova J, Truxova I, Tachezy R, Spisek R, Fialova A (2015) Distinct patterns of intratumoral immune cell infiltrates in patients with HPV-associated compared to non-virally induced head and neck squamous cell carcinoma. Oncoimmunology 4(1): e965570.

Pretscher D, Distel LV, Grabenbauer GG, Wittlinger M, Buettner M, Niedobitek G (2009) Distribution of immune cells in head and neck cancer: CD8 + T-cells and CD20 + B-cells in metastatic lymph nodes are associated with favourable outcome in patients with oro- and hypopharyngeal carcinoma. BMC Cancer 9: 292.

Punt S, Dronkers EA, Welters MJ, Goedemans R, Koljenovic S, Bloemena E, Snijders PJ, Gorter A, van der Burg SH, Baatenburg de Jong RJ, Jordanova ES (2016) A beneficial tumor microenvironment in oropharyngeal squamous cell carcinoma is characterized by a high $\mathrm{T}$ cell and low IL-17( + ) cell frequency. Cancer Immunol Immunother 65(4): 393-403.

Saldanha G, Flatman K, Teo KW, Bamford M (2017) A novel numerical scoring system for melanoma tumor-infiltrating lymphocytes has better prognostic value than standard scoring. Am J Surg Pathol 41(7): 906-914.

Salgado R, Denkert C, Demaria S, Sirtaine N, Klauschen F, Pruneri G, Wienert S, Van den Eynden G, Baehner FL, Penault-Llorca F, Perez EA, Thompson EA, Symmans WF, Richardson AL, Brock J, Criscitiello C, Bailey H, Ignatiadis M, Floris G, Sparano J, Kos Z, Nielsen T, Rimm DL,
Allison KH, Reis-Filho JS, Loibl S, Sotiriou C, Viale G, Badve S, Adams S, Willard-Gallo K, Loi S (2015) The evaluation of tumor-infiltrating lymphocytes (TILs) in breast cancer: recommendations by an International TILs Working Group 2014. Ann Oncol 26(2): 259-271.

Santoiemma PP, Powell Jr DJ (2015) Tumor infiltrating lymphocytes in ovarian cancer. Cancer Biol Ther 16(6): 807-820.

Schreiber RD, Old LJ, Smyth MJ (2011) Cancer immunoediting: integrating immunity's roles in cancer suppression and promotion. Science 331: 1565-1570.

Shankaran V (2001) IFN $\gamma$ and lymphocytes prevent primary tumour development and shape tumour immunogenicity. Nature 410: 1107-1111.

Sharma P, Shen Y, Wen S, Yamada S, Jungbluth AA, Gnjatic S, Bajorin DF, Reuter VE, Herr H, Old LJ, Sato E (2007) CD8 tumor-infiltrating lymphocytes are predictive of survival in muscle-invasive urothelial carcinoma. Proc Natl Acad Sci USA 104(10): 3967-3972.

Sideras K, Biermann K, Verheij J, Takkenberg BR, Mancham S, Hansen BE, Schutz HM, de Man RA, Sprengers D, Buschow SI, Verseput MC, Boor PP, Pan Q, van Gulik TM, Terkivatan T, Ijzermans JN, Beuers UH, Sleijfer S, Bruno MJ, Kwekkeboom J (2017) PD-L1, Galectin-9 and CD8 + tumor-infiltrating lymphocytes are associated with survival in hepatocellular carcinoma. Oncoimmunology 6(2): e1273309.

Sjodahl G, Lovgren K, Lauss M, Chebil G, Patschan O, Gudjonsson S, Mansson W, Ferno M, Leandersson K, Lindgren D, Liedberg F, Hoglund M (2014) Infiltration of CD3(+) and CD68 (+) cells in bladder cancer is subtype specific and affects the outcome of patients with muscleinvasive tumors. Urol Oncol 32(6): 791-797.

Song H, Wu Y, Ren G, Guo W, Wang L (2015) Prognostic factors of oral mucosal melanoma: histopathological analysis in a retrospective cohort of 82 cases. Histopathology 67(4): 548-556.

Stoll G, Bindea G, Mlecnik B, Galon J, Zitvogel L, Kroemer G (2015) Meta-analysis of organ-specific differences in the structure of the immune infiltrate in major malignancies. Oncotarget 6(14): 11894-11909.

Sun DS, Zhao MQ, Xia M, Li L, Jiang YH (2012) The correlation between tumor-infiltrating Foxp3 + regulatory T cells and cyclooxygenase- 2 expression and their association with recurrence in resected head and neck cancers. Med Oncol 29(2): 707-713.

Sun C, Xu J, Song J, Liu C, Wang J, Weng C, Sun H, Wei H, Xiao W, Sun R, Tian Z (2015) The predictive value of centre tumour CD8(+) T cells in patients with hepatocellular carcinoma: comparison with Immunoscore. Oncotarget 6(34): 35602-35615.

Thomas NE, Busam KJ, From L, Kricker A, Armstrong BK, Anton-Culver H, Gruber SB, Gallagher RP, Zanetti R, Rosso S, Dwyer T, Venn A, Kanetsky PA, Groben PA, Hao H, Orlow I, Reiner AS, Luo L, Paine S, Ollila DW, Wilcox H, Begg CB, Berwick M (2013) Tumor-infiltrating lymphocyte grade in primary melanomas is independently associated with melanoma-specific survival in the population-based genes, environment and melanoma study. J Clin Oncol 31(33): 4252-4259.

Tu J-F, Ding Y-H, Ying X-H, Wu F-Z, Zhou X-M, Zhang D-K, Zou H, Ji J-S (2016) Regulatory T cells, especially ICOS + FOXP3 + regulatory T cells, are increased in the hepatocellular carcinoma microenvironment and predict reduced survival. Sci Rep 6: 35056.

Ugel S, De Sanctis F, Mandruzzato S, Bronte V (2015) Tumor-induced myeloid deviation: when myeloid-derived suppressor cells meet tumorassociated macrophages. J Clin Invest 125(9): 3365-3376.

Wang B, Wu S, Zeng H, Liu Z, Dong W, He W, Chen X, Dong X, Zheng L, Lin T, Huang J (2015) CD103 + tumor infiltrating lymphocytes predict a favorable prognosis in urothelial cell carcinoma of the bladder. J Urol 194(2): 556-562.

Wang Q, Luan W, Warren L, Fiel MI, Blank S, Kadri H, Mandeli J, Hiotis SP (2016) Prognostic role of immune cells in hepatitis B-associated hepatocellular carcinoma following surgical resection depends on their localization and tumor size. J Immunother 39(1): 36-44.

Wansom D, Light E, Thomas D, Worden F, Prince M, Urba S, Chepeha D, Kumar B, Cordell K, Eisbruch A, Taylor J, Moyer J, Bradford C, D'Silva N, Carey T, McHugh J, Wolf G (2012) Infiltrating lymphocytes and human papillomavirus-16-associated oropharyngeal cancer. Laryngoscope 122(1): 121-127.

Ward MJ, Thirdborough SM, Mellows T, Riley C, Harris S, Suchak K, Webb A, Hampton C, Patel NN, Randall CJ, Cox HJ, Jogai S, Primrose J, Piper K, Ottensmeier CH, King EV, Thomas GJ (2014) Tumourinfiltrating lymphocytes predict for outcome in HPV-positive oropharyngeal cancer. Br J Cancer 110(2): 489-500.

Weiss SA, Han SW, Lui K, Tchack J, Shapiro R, Berman R, Zhong J, Krogsgaard M, Osman I, Darvishian F (2016) Immunologic heterogeneity 
of tumor-infiltrating lymphocyte composition in primary melanoma. Hum Pathol 57: 116-125.

Wolf GT, Chepeha DB, Bellile E, Nguyen A, Thomas D, McHugh J (2015) Tumor infiltrating lymphocytes (TIL) and prognosis in oral cavity squamous carcinoma: a preliminary study. Oral Oncol 51(1): 90-95.

Xu Q, Wang C, Yuan X, Feng Z, Han Z (2017) Prognostic value of tumorinfiltrating lymphocytes for patients with head and neck squamous cell carcinoma. Transl Oncol 10(1): 10-16.

Zhang L (2003) Intratumoral T cells, recurrence, and survival in epithelial ovarian cancer. N Engl J Med 348: 203-213.

Zhang Q, Hao C, Cheng G, Wang L, Wang X, Li C, Qiu J, Ding K (2015) High $\mathrm{CD} 4(+) \mathrm{T}$ cell density is associated with poor prognosis in patients with non-muscle-invasive bladder cancer. Int J Clin Exp Pathol 8(9): 1151011516.

Zhao HQ, Li WM, Lu ZQ, Yao YM (2014) Roles of Tregs in development of hepatocellular carcinoma: a meta-analysis. World J Gastroenterol 20(24): 7971-7978.

(c) (i) (2) This work is licensed under the Creative Commons cc. Attribution-Non-Commercial-Share Alike 4.0 International License. To view a copy of this license, visit http:// creativecommons.org/licenses/by-nc-sa/4.0/

(C) The Author(s) named above 2017 